\title{
A Study on Transhipment Model for Export of Rubber from Tripura to Bangladesh
}

\author{
Nabendu Sen and Manish Nandi \\ Department of Mathematics, Assam University, Silchar-788011, India
}

\begin{abstract}
Production of rubber in Tripura is the second largest after Kerala. But a less quantity is locally utilized compare to other rubber producing states. A large quantity of rubber is transported to different parts of the country. But transportation costs at present is not so much favourable for the firms or agencies due to frequent price hike of petroleum. Bangladesh is the neighbouring country of Tripura. Bilateral trading now a days is functioning smoothly. Industrialization in rubber sector in Bangladesh needs a sizable quantity of rubber. For exportation of rubber from Tripura to Bangladesh, a transhipment model is considered to minimize the transportation costs.
\end{abstract}

Keywords: Transhipment model, Vogel's Approximation Method, Optimal Solution etc.

\section{Introduction:}

Tripura, a beautiful green hilly state, surrounded by natural beauty, eye witness of birth of Bangladesh, turns dubious when debate for development takes place. Climate of Tripura offers wide range of opportunities for the cultivation of various food crops, fruits, vegetables and flowers and plantation crops. Rubber plantation in Tripura has gained its momentum at present. According to survey report by Rubber Board of India, one lakh hectares land area can be utilized for rubber plantation. At present 58 thousand hectares land area is covered where rubber plantation is taken place. In Tripura, rubber plantation and rubber related other activities has an important role for the development of the socio-economic status of the State.

Rubber is the important cash crops of the state. Tripura has been declared the Second Rubber Capital of India after Kerala. Good about Tripura is that it is located on strategically strong position. On three fronts, it is surrounded by Bangladesh. On one front it is connected with Assam and Mizoram which is linked with Myanmar. Tripura's strategic location can be exploited through bilateral trade, whether it is with Bangladesh, China, Myanmar, Nepal or Bhutan. On three sides, Tripura, in the past, had excellent transportation links with the then East Bengal. Many large towns in Bangladesh are within 150 kilometres of the towns in Tripura. Border trade with Bangladesh will effectively integrate the Tripura Economy to the rest of India as well as to the other countries in the Region. In fact, it will make Tripura 'Gate Way' to the "North East" and will give a great boast to the state economy. This would open up a vast market for the industrial units specially Rubber Industry units in Tripura. Facilitating cargo movement by using the land ports between Tripura and Bangladesh will cut down on transport cost for the producers who sell their product to the main land rubber goods industries.

\section{Problem Statement:}

Rubber has been identified as one of the thrust area in Tripura. Tripura is the second largest rubber producer in the country, after Kerala. The total area under rubber plantations in Tripura at present is nearly 58,000 hectares and produced nearly 28,000 tone of natural rubber. But merely $6-7 \%$ of total production is locally utilised. Several agencies working in Tripura export rubber to many states and also many countries. Neighbouring country Bangladesh is one of major rubber importer from Tripura. On the basis of available data collected from locally working agencies, a transhipment model is developed. 23 sub-divisions of Tripura are divided into 4 zones and we consider two land custom stations as buffer for transportation.

We consider $Z_{1}, Z_{2}, Z_{3}, Z_{4}$ for four zones, $A$ (Akhaura) and $B$ (Srimantapur) for land custom stations as transit centres and $\mathrm{X}(\mathrm{Dhaka}), \mathrm{Y}($ Comilla) as destinations where rubber will be exported. Data collected from the source is given below:-

\begin{tabular}{|c|c|c|c|c|c|}
\hline & A & B & X & Y & Supply \\
\hline $\mathrm{Z}_{1}$ & 2750 & 3500 & ---- & ---- & 1000 \\
\hline $\mathrm{Z}_{2}$ & 2675 & 2500 & ---- & ---- & 700 \\
\hline $\mathrm{Z}_{3}$ & 5400 & 2600 & ---- & ---- & 1200 \\
\hline $\mathrm{Z}_{4}$ & 7600 & 9780 & ---- & ----- & 600 \\
\hline $\mathrm{A}$ & 0 & 3400 & 9000 & 16750 & \\
\hline $\mathrm{B}$ & ---- & 0 & 15650 & 1600 & \\
\hline Demand & ---- & --- & 0 & 7500 & \\
\hline
\end{tabular}


Transportation costs given in the table is in Rupees per 25 tons. On the Basis of the given data we construct a transhipment network between sources and destinations.

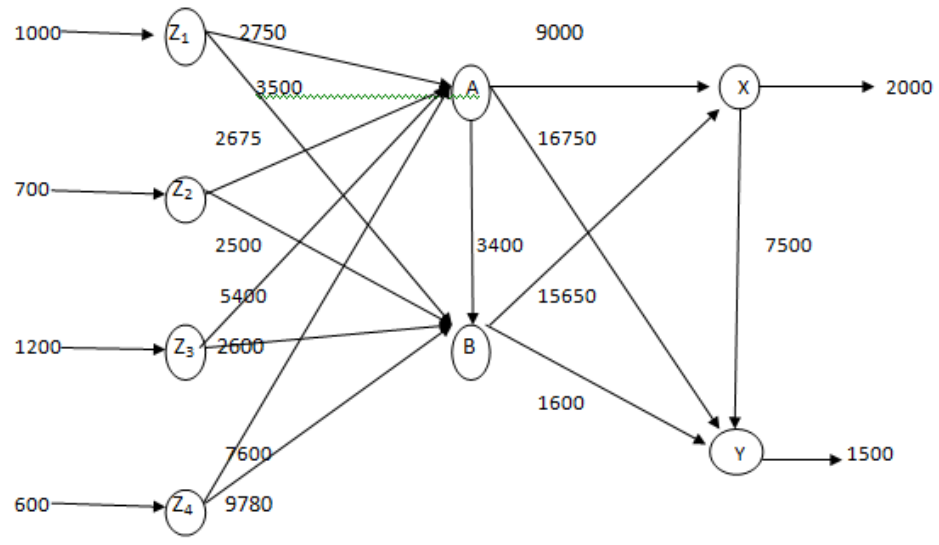

Figure 1: Transhipment Network between sources and destinations.

III. Model Formulation:

The transhipment model can be converted into a regular transportation model with seven sources $\left(\mathrm{Z}_{1}, \mathrm{Z}_{2}\right.$, $\left.\mathrm{Z}_{3}, \mathrm{Z}_{4}, \mathrm{~A}, \mathrm{~B}, \mathrm{X}\right)$ and four destinations ( $\left.\mathrm{A}, \mathrm{B}, \mathrm{X}, \mathrm{Y}\right)$. The formulated model is

Minimize $Z=\sum \sum \mathrm{c}_{\mathrm{ij}} \mathrm{X}_{\mathrm{ij}}$ where $\mathrm{i}=1,2, \ldots . ., 7 ; \mathrm{j}=1,2,3,4$

Subject to $\quad \sum \mathrm{x}_{\mathrm{ij}}=\mathrm{a}_{\mathrm{i}}, \mathrm{i}=1,2, \ldots . ., 7$ (Supply constraints ), $\mathrm{j}=1,2,3,4$

$\sum \mathrm{x}_{\mathrm{ij}}=\mathrm{b}_{\mathrm{j}}, \mathrm{j}=1,2,3,4$ (demand constraints ), $\mathrm{i}=1,2, \ldots ., 7$ and $x_{i j} \geq 0$ for all $i$ and $j$

where $x_{i j}=$ number of units of the product in ton to be transported from source $\quad i(i=1,2, \ldots, 7)$ to destination $\mathrm{j}(\mathrm{j}=1,2,3,4)$

$\mathrm{C}_{\mathrm{ij}}=$ cost of units (Rupees per 25 tons )

The amount of supply and demand different at the different nodes are computed :

Supply at a pure supply node $\left(\mathrm{Z}_{1}, \mathrm{Z}_{2}, \mathrm{Z}_{3}, \mathrm{Z}_{4}\right)=$ Original supply

Demand at a pure demand node $(X, Y)=$ Original demand

Supply at a transhipment node $(\mathrm{A}, \mathrm{B}, \mathrm{X})=$ Original supply + Buffer amount

Demand at a transhipment node $=$ Original demand + buffer amount .

In this problem buffer amount $=$ Total supply $($ or demand $)$

$100+700+1200+600($ or $2000+1500)$

$=3500$ tons.

In this present problem, transportation from certain sources to certain destinations is not possible. We can handle the problem by assigning very large cost by $\mathrm{M}$.

\section{Solution:}

To find out the solution of the present problem, we apply more desirable solution method, Vogel's approximation method.

\begin{tabular}{|c|c|c|c|c|c|c|c|}
\hline \multicolumn{8}{|c|}{ Vogel's Approximation Method (VAM) } \\
\hline & \multicolumn{2}{|c|}{ A } & \multicolumn{2}{|c|}{ B } & $\mathrm{X}$ & $\mathrm{Y}$ & Supply \\
\hline \multirow[t]{2}{*}{$Z_{1}$} & 2750 & & \multirow{2}{*}{\multicolumn{2}{|c|}{3500}} & \multirow{2}{*}{$\mathrm{M}$} & \multirow{2}{*}{ M } & \multirow{2}{*}{1000} \\
\hline & & 1000 & & & & & \\
\hline \multirow[t]{2}{*}{$\overline{Z_{2}}$} & 2675 & & \multirow[t]{2}{*}{2500} & & \multirow{2}{*}{ M } & \multirow{2}{*}{ M } & \multirow{2}{*}{700} \\
\hline & & 400 & & 300 & & & \\
\hline \multirow[t]{2}{*}{$\overline{Z_{3}}$} & & & \multicolumn{2}{|l|}{2600} & \multirow[b]{2}{*}{$\mathrm{M}$} & \multirow[b]{2}{*}{ M } & \multirow[b]{2}{*}{1200} \\
\hline & & 00 & & 1200 & & & \\
\hline \multirow[t]{2}{*}{$\mathrm{Z}_{4}$} & \multicolumn{2}{|l|}{7600} & \multirow{2}{*}{\multicolumn{2}{|c|}{9780}} & \multirow{2}{*}{$\mathrm{M}$} & \multirow{2}{*}{$\mathrm{M}$} & \multirow{2}{*}{600} \\
\hline & & 600 & & & & & \\
\hline
\end{tabular}




\begin{tabular}{|c|c|c|c|c|c|}
\hline \multirow[t]{2}{*}{ A } & 0 & \multirow{2}{*}{3400} & 9000 & \multirow{2}{*}{16750} & \multirow{2}{*}{3500} \\
\hline & 1500 & & 2000 & & \\
\hline \multirow[t]{2}{*}{ B } & \multirow{2}{*}{$\mathrm{M}$} & 0 & \multirow{2}{*}{15650} & 1600 & \multirow{2}{*}{3500} \\
\hline & & 2000 & & 1500 & \\
\hline \multirow[t]{2}{*}{$\mathrm{X}$} & \multirow{2}{*}{ M } & \multirow{2}{*}{ M } & 0 & \multirow{2}{*}{7500} & \multirow{2}{*}{3500} \\
\hline & & & 3500 & & \\
\hline Demand & 3500 & 3500 & 5500 & 1500 & 14000 \\
\hline
\end{tabular}

Initial basic solution ---

$X_{11}=1000, X_{21}=400, X_{22}=300, X_{32}=1200, X_{41}=600, X_{51}=1500, X_{53}=2000, X_{62}=2000, X_{64}=1500, X_{73}=$ 3500 .

Min Cost $=$ Rs. $(2750 \times 1000+2675 \times 400+2500 \times 300+2600 \times 1200+7600 \times 600+0 \times 1500+9000 \times 2000+$ $0 \times 2000+1600 \times 1500+0 \times 3500) / 25$

$=$ Rs.13,02,000/-

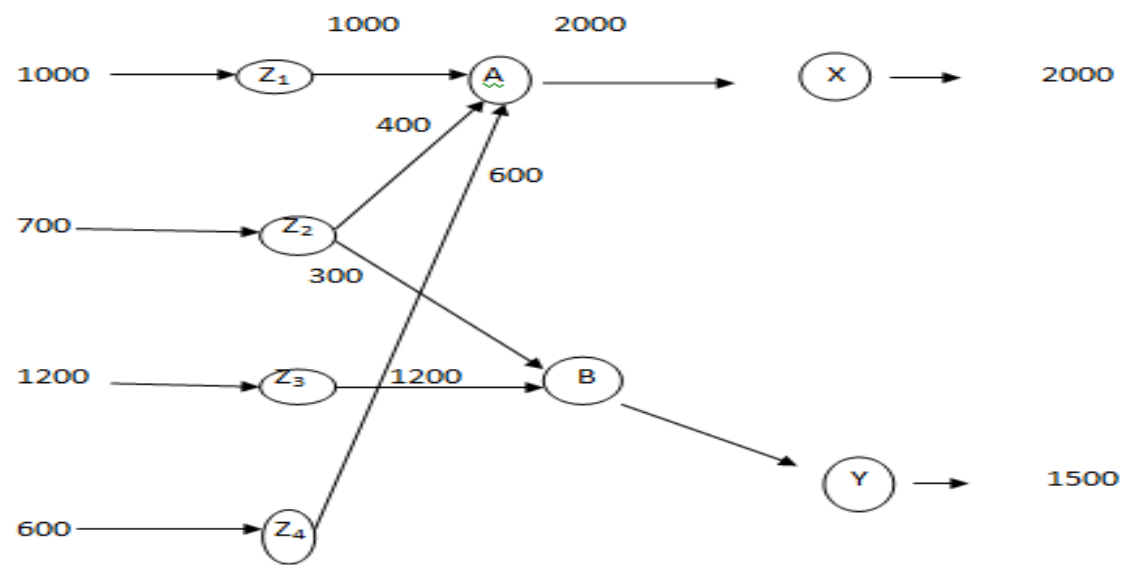

Figure 2: Solution of the transhipment model.

V. Optimality Test-MODI Method:

The quantities $\left(u_{i}+v_{j}\right)$ for the unoccupied cells are displayed in the circles.

Optimality test table

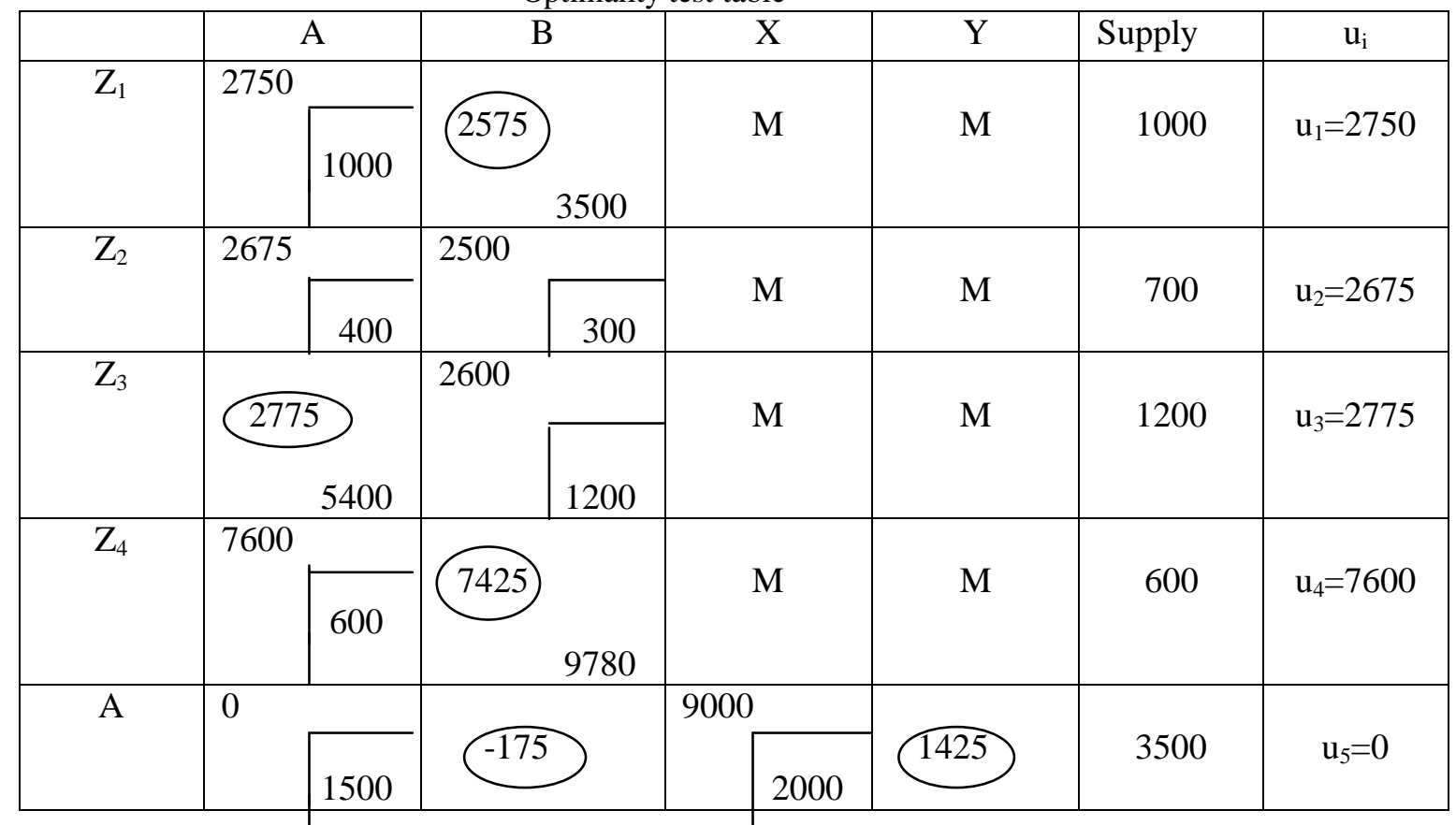


A Study on Transhipment Model for Export of Rubber from Tripura to Bangladesh

\begin{tabular}{|c|c|c|c|c|c|c|}
\hline & & 3400 & & 16750 & & \\
\hline \multirow[t]{2}{*}{ B } & \multirow{2}{*}{ M } & 0 & & 1600 & \multirow{2}{*}{3500} & \multirow{2}{*}{$\mathrm{u}_{6}=175$} \\
\hline & & 2000 & 15650 & 1500 & & \\
\hline \multirow[t]{2}{*}{ X } & \multirow{2}{*}{ M } & \multirow{2}{*}{ M } & 0 & \multirow{2}{*}{$\underbrace{-7575}_{7500}$} & \multirow{2}{*}{3500} & \multirow{2}{*}{$\mathrm{u}_{7}=-9000$} \\
\hline & & & 3500 & & & \\
\hline Demand & 3500 & 3500 & 5500 & 1500 & 14000 & \\
\hline $\mathrm{v}_{\mathrm{j}}$ & $\mathrm{v}_{1}=0$ & $\mathrm{v}_{2}=-175$ & $\mathrm{v}_{3}=9000$ & $\mathrm{v}_{4}=1425$ & & \\
\hline
\end{tabular}

We compute $\Delta_{i j}=c_{i j}-\left(u_{i}+v_{j}\right)$, the cell evaluations, for the unoccupied cells.

\begin{tabular}{|c|c|c|c|}
\hline & 925 & & \\
\hline & & & \\
\hline 2625 & & & \\
\hline & 2355 & & \\
\hline & 3575 & & 15325 \\
\hline & & 6475 & \\
\hline & & & 15075 \\
\hline
\end{tabular}

$\Delta_{12}=925, \Delta_{31}=2625, \Delta_{42}=2355, \Delta_{52}=3575, \Delta_{54}=15325, \Delta_{63}=6475, \Delta_{74}=15075$

Since all $\Delta_{\mathrm{ij}}>0$, the solution under test is optimal. Thus the optimal solution is

$X_{11}=1000, X_{21}=400, X_{22}=300, X_{32}=1200, X_{41}=600, X_{51}=1500, X_{53}=2000, X_{62}=2000$,

$\mathrm{X}_{64}=1500, \mathrm{X}_{73}=3500$.

Min Cost $=$ Rs. $(2750 \times 1000+2675 \times 400+2500 \times 300+2600 \times 1200+7600 \times 600+0 \times 1500+9000 \times 2000+0 \times 2000$

$+1600 \times 1500+0 \times 3500) / 25$

$=$ Rs.13,02,000/-.

\section{Conclusion:}

In this paper, we consider two land custom stations to transport rubber sheet from Tripura to Bangladesh. The optimal solution obtained in this present investigation is same with initial basic feasible solution which we obtained by applying Vogel's approximation method. This model can be applied also for more than two transit points. Our motto is to minimize the transport cost. This model is useful in other sectors also.

\section{References}

[1] A. Jarzemskis, Assumptions of small scale intermodal transport, Transport 2008; 23(1), 16-20.

[2] C. Perng and, Z.P. Ho, Receiving and Shipping Management in a Transhipment Centre, Asian Journal of Management and Humanity Sciences 2007; 1(4), 514-522.

[3] G.B. Dantzig, Linear Programming and Extensions, Princeton, N.J.: Princeton University 1963.

[4] H.A. Taha (). Operation Research: An Introduction, Prentice Hall, $7^{\text {th }}$ Edition, USA 1996.

[5] J. Reeb and, S. Leavengood, Transportation Problem: A special case for Linear Programming Problems, Performance Excellence in the Wood Products Industry, EM 8779, Oregon State University, USA 2002.

[6] K. Yamashita, Y. Karuno And M. Lu, An Inapproximability of Transhipment Problems with Per mutable Transit Vectors, Journal of the Operations Research Society of Japan 2010; 53(3), 220-234.

[7] N. Sen, T. Som And B. Sinha, A study of Transportation Problem for an Essential Item of Southern Part of North Eastern Region of India as an OR Model and Use of Object Oriented Programming, International Journal of Computer Sciences and Networking Security 2010; 10(4), 78-86.

[8] S. Kikuchi, J. Rhee And D. Teodorvic, Applicability of an Agent based Modeling Concept to Modeling of Transportation Phenomena, Yugoslav Journal of Operation Research 2002; 12(2), 141-156.

[9] T. Imam , G. Elsharawy, M. Gomah and I. Samy, Solving Transportation Problem Using Object-Oriented Model, International Journal of Computer Science and Network Security 2009; 9(2), 353-361.

[10] V. Adlakha and, H. Arsham, Managing Cost Uncertainties in Transportation and Assignment Problems, Journal of Applied Mathematics and Decision Sciences 1998; 2(1), 65-104.

[11] Y.T. Herer, , M. Tzur And, E. Yucesan (). The Multi-location Transshipment Problem, IIE Transactions 2006 ;38, $185-200$. 